\title{
DYNAMIC SIMULATION OF A PV/WIND HYBRID POWER GENERATION SYSTEM: CASE STUDY OF BURSA PROVINCE
}

Ayşe Fidan ALTUN*

Muhsin KILIÇ*

Received: 02.07.2019 ; revised: 22.07.2019 ; accepted: 02.08.2019

\begin{abstract}
In this study, a PV/Wind hybrid power generation system was studied using meteorological data of Bursa province. Reliability of the weather data is crucial when designing renewable-based power systems. As a result, weather data of the two specific years $(2011,2014)$ were chosen for the dynamic simulations. The designed hybrid system consists of PV panels and a wind turbine. The outcome of the study shows that with the proposed $1 \mathrm{MW} \mathrm{PV}+2 \mathrm{MW}$ wind turbine system, it is possible to generate enough electricity to compensate the annual electricity requirement of 450 households which can be considered as a small district area. Levelized cost of energy is found a value between 0.413-0.568 $\$ / \mathrm{kWh}$. Payback period of the system is found a value around 20 years. It was concluded that it is essential to offer adequate incentives for renewable-based power applications to make them economically beneficial.
\end{abstract}

Keywords: Wind, solar, PV, Hybrid

\section{Bir Fotovoltaik/Rüzgar Türbini Hibrit Güç Üretim Santralinin Dinamik Simulasyonu: Bursa İli Örneği}

Öz: Bu çalışmada, bir fotovoltaik/rüzgar türbini hibrit güç üretim santrali, Bursa ilinin meteorolojik verileri kullanılarak çalışılmıştır. Yenilenebilir enerji sistemlerinin tasarımında hava verisinin güvenilirliği büyük önem arz eder. Bu sebeple dinamik simülasyonda kullanılmak üzere iki spesifik yıl (2011 ve 2014) belirlenmiştir. Tasarlanan hibrit sistem, fotovoltaik güneş panelleri ile bir rüzgar türbininden oluşmaktadır. Çalışmanın sonuçları, 1 MW kapasitede fotovoltaik panel ve 2 MW kapasitede rüzgar türbini kullanılarak oluşturulan hibrit sistem ile 450 haneden oluşan küçük bir yerleşim bölgesinin yıllık elektrik ihtiyacını karşılamanın mümkün olduğunu göstermiştir. Hibrit güç üretim sistemi ile üretilen enerjinin birim fiyatının 0.413-0.568 \$/kWh aralığında olduğu görülmüştür. Ayrıca tasarlanan sistemin geri ödeme süresinin 20 yıl civarında olduğu hesaplanmıştır. Bu sistemlerin ekonomik anlamda yatırımcıya daha cazip hale gelebilmesi için devletin daha faydalı teşvikler sunması kaçınılmazdır.

Anahtar Kelimeler: Rüzgar, güneş, fotovoltaik, hibrit

\section{INTRODUCTION}

Energy is the most important parameter for the economic and social development of any country. Today, the annual global energy requirement is 16 Terra Watt, and most of it comes from fossil fuels. Sustainable energy has significant importance for the sustainable development of Turkey, as it imports approximately $70 \%$ of its energy requirement (Kaya et al.,

\footnotetext{
"Bursa Uludag University, Department of Mechanical Engineering, Bursa,Turkey Correspondence Author: Muhsin Kilic (․kilic@uludag.edu.tr)
} 
2017). Effective use of its own resources has become crucial (Kok and Benli, 2017). Renewable energy resources are considered as clean sources of energy, and they help to diversify energy portfolios and decrease import-based energy dependency (Erdil and Erbiyık, 2015). Turkey has a significant amount of renewable energy sources. As a result, renewable-based power systems can be considered as effective solutions for sustainable development of Turkey in the long term.

Reliability and cost are two important aspects that must be taken into account when working with renewable energy systems for the generation of electricity (Bernal-Agustin and Dufo-Lopez, 2009). Since it is not possible to have access to abundant wind or abundant solar radiation all the time, wind-solar hybrid systems are increasing attention. In this way, energy generation becomes more reliable because one type of energy source can offset the shortfall of the other (Acevedo et al., 2016). There are some studies regarding hybrid renewable energy systems in the literature. Bakic et al. (2012) studied a PV/wind integrated hybrid power energy system for the city of Belgrade. The hybrid system was comprised of $3 \mathrm{~kW}$ capacity PV modules and 1, 3 or $5 \mathrm{~kW}$ capacity wind turbine. They used TRNSYS software for dynamic simulations. Results of the study show that, with PV and $5 \mathrm{~kW}$ wind turbine, it is possible to generate $8890 \mathrm{kWh}$ electricity annually for the Belgrade city. $\mathrm{CO}_{2}$ emissions reduction was also estimated in that paper. Panayiotou et al. (2012) designed and simulated a PV and PV-wind standalone energy system for the weather conditions of Nicosia, Cyprus and Nice, France. Results of the study showed that for the case of a hybrid system, Nice shows greater performance due to the much better wind profile and application of a hybrid system should not be considered for Nicosia since it is not economically feasible. Huang et al. (2015) proposed a new hybrid system which was comprised of multiple small wind turbines instead of a large one and power outputs of two hybrid systems were compared under various climates in China. Results of the study showed that using multiple, small wind turbines instead of a large one, increases the power output by $18.69 \% 31.24 \%$ and $53.79 \%$ when used in Shenyang, Shangai and Guangzhou, respectively. Ramli et al. (2016) investigated the potential of a wind/solar hybrid system for the western coastal area of Saudi Arabia using MATLAB and HOMER software. Results of the study showed that PV array produces greater electricity than the wind turbines with the same capacity. Also, the authors concluded that levelized cost of energy is $0.149 \$ / \mathrm{kWh}$ for wind and $0.0637 \$ / \mathrm{kWh}$ for solar energy.

In this study, design and simulation of a renewable-based hybrid power system were presented with using meteorological data of Bursa province. Two specific years (2011 and 2014) were chosen for the study. Performance of the system was studied with dynamic simulations. The proposed system was comprised of a $2 \mathrm{MW}$ capacity wind turbine and $1 \mathrm{MW}$ capacity photovoltaic (PV) modules. In terms of wind energy, power outputs of three different wind turbine types with the same capacity were investigated. The power output of the same wind turbine at different heights was also investigated. In terms of solar power, different PV slope angles were studied, and results were compared. In addition to energy analysis, an economic analysis was also conducted to see the feasibility of the proposed system. The overall motivation of the study is to explore the renewable energy potential of Bursa province.

\section{MATERIALS AND METHODS}

Photovoltaic and wind power generation is directly related to weather variability. As a result, weather data is very critical to design a renewable energy-based power plant properly. In order to increase the reliance on the results, hourly weather data of two different years were used separately, instead of using data from a single year. Meteorological data of Bursa, such as ambient temperature, wind speed, total global radiation for the year of 2011 and 2014 were obtained from Turkish State Meteorological Service. The meteorological data were measured in Yunuseli Meteorological Station of Bursa Province, which is near the Bursa, Yunuseli airport. 


\subsection{Wind Energy Potential of Bursa Province}

The mean monthly wind speed of Bursa is presented in figure 1. The data is obtained by measuring wind speed at $10 \mathrm{~m}$ height, and it is extrapolated by using the power law for the different heights (Ramli et al., 2016);

$$
u_{2}=u_{1}\left(\frac{z_{2}}{z_{1}}\right)^{a}
$$

In Eq.(1), $u_{2}$ is the wind speed at the hub height $(\mathrm{m} / \mathrm{s}), u_{1}$ is the wind speed at the anemometer height $(\mathrm{m} / \mathrm{s}), z_{2}$ is the hub height $(\mathrm{m})$, and $z_{1}(\mathrm{~m})$ is the anemometer height. " $a$ " is the wind shear exponent based on the boundary layer conditions, and it is generally taken as $1 / 7$ (Elnaggar et al. 2017). Wind speed is an essential factor that influences the wind turbine's performance. As shown in figure 1, an increase of the height leads to a rise of the wind speed. However, wind turbines are usually not considered practical at high elevations, despite the stronger wind speeds (Rohatgi and Vaughn, 1974). In order to determine the annual wind speed profile of Bursa, the mean monthly wind speed of the year 2011 and 2014 was presented in figure 2. It can be observed that the lowest wind speed over an entire year was measured in November for both years. Highest average mean monthly wind speed was measured in April for the year of $2011(3 \mathrm{~m} / \mathrm{s})$ and, January for the year of $2014(3.5 \mathrm{~m} / \mathrm{s})$. It can be noticed that, average monthly mean wind velocity of Bursa changes between 2 to $3.5 \mathrm{~m} / \mathrm{s}$. For both two years, wind speed has a decreasing trend from August to November and an increasing tendency from May to August.

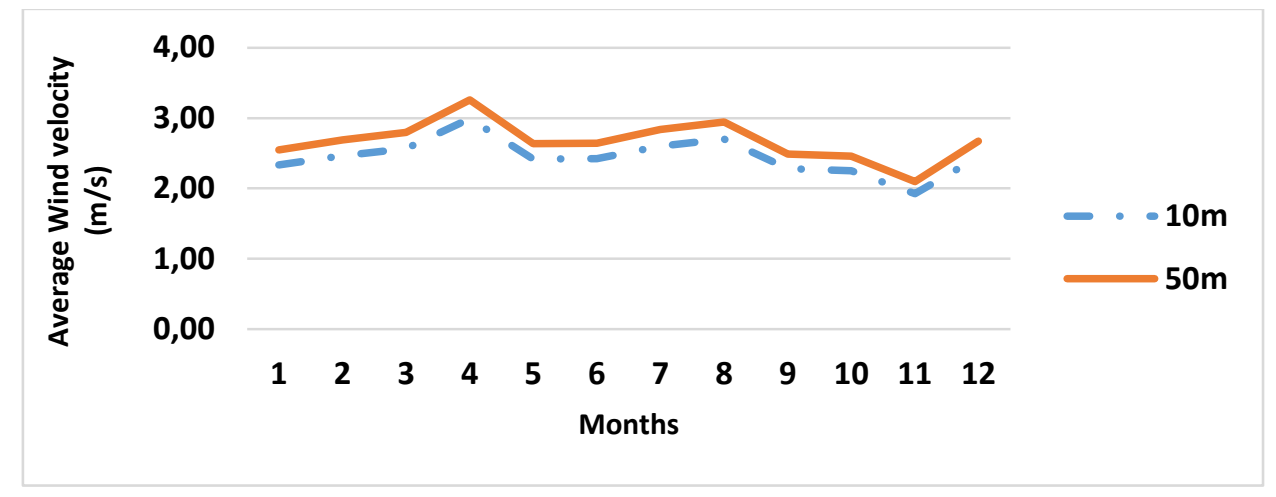

Figure 1:

Average monthly wind speed of Bursa for the year of 2011 at different heights

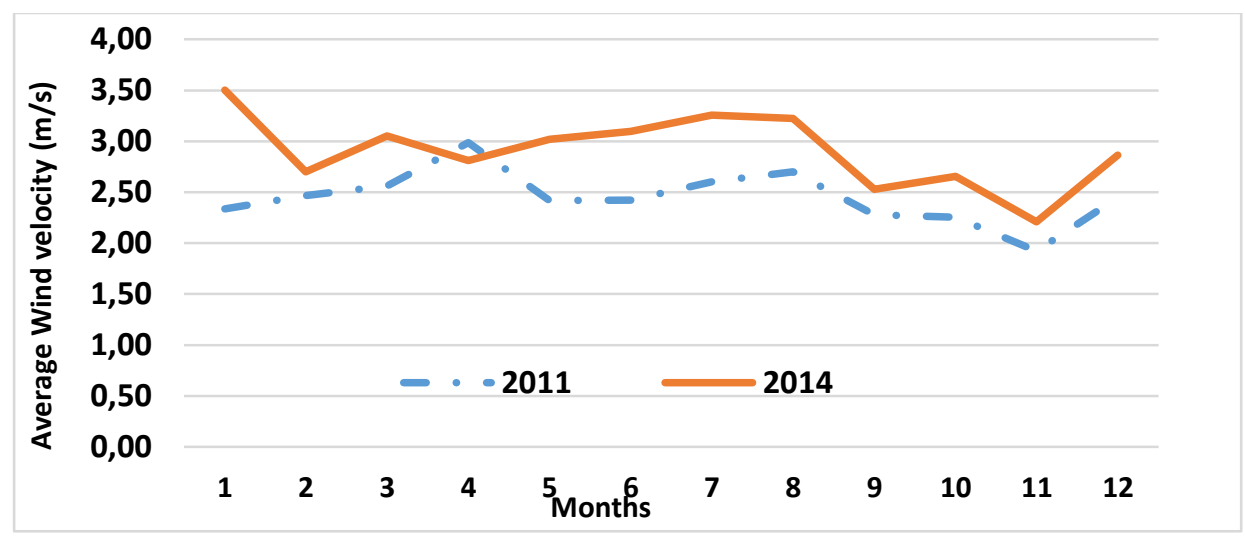

Figure 2:

Average monthly wind speed of Bursa for the year of 2011 and 2014 (at reference height of $10 m)$ 


\subsection{Wind Turbine Calculations}

The coefficient of power $\mathrm{C}_{\mathrm{p}}$ is a very important parameter, which is a measurement of how efficiently the wind turbine converts the kinetic energy in the wind, into electrical energy. $\mathrm{C}_{\mathrm{p}}$ is a ratio of power produced by the turbine divided by the total wind power flowing into the turbine blades (Elnaggar et al., 2017), and it is presented in Eq. (2).

$$
\begin{gathered}
C_{p}=\frac{\text { Actual electrical power produced }}{\text { Wind Power into Turbine }}=\frac{P_{\text {out }}}{P_{\text {in }}} \\
P_{\text {out }}=C_{P} \cdot \rho \cdot A_{R} U_{0}{ }^{3}
\end{gathered}
$$

The value of power coefficient $\left(\mathrm{C}_{\mathrm{p}}\right)$ is when multiplied by the area of the rotor and power in the wind, it describes the real power output of the wind turbine. Wind turbines cannot convert more than 59.3 per cent of the kinetic energy to mechanical energy, and this is known as Betz limit (Tank et al. 2016).

TRNSYS is a well-known dynamic simulation program. Type 90 wind energy conversion system was selected from the program library for wind turbine modelling. Type 90 reads the wind turbine performance data (power versus wind speed characteristic) from a separate data file. Performance data files of three different wind turbine models were collected from the producers. In figure 3 , the power curve of the selected turbine models was presented. In Table 1 , technical specifications of the wind turbine types were presented. In this table, start wind speed is the speed that the turbine starts producing power.

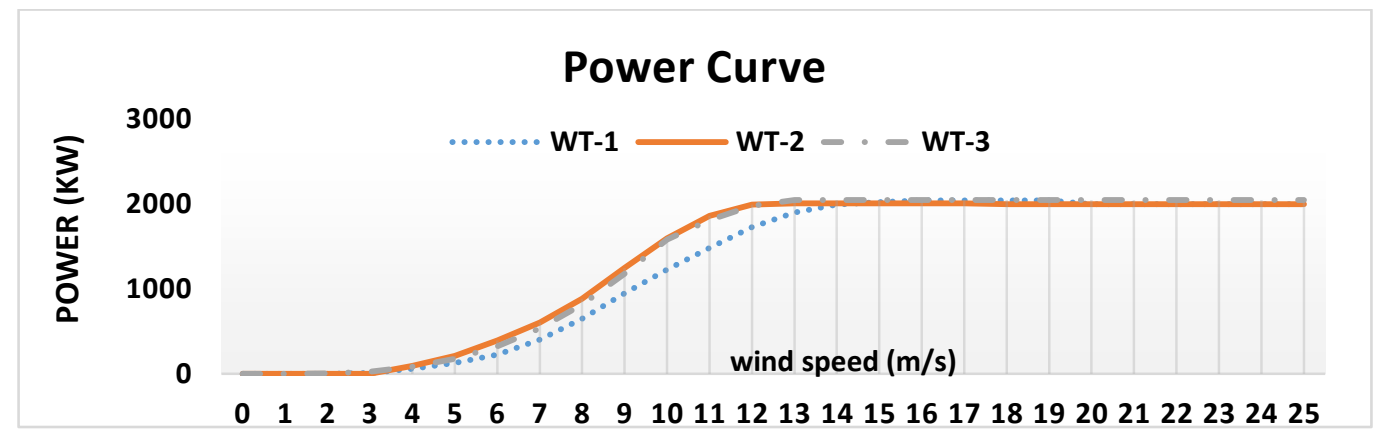

Figure 3:

Power curve of selected wind turbine models

Table 1. Wind Turbine Specifications

\begin{tabular}{|c|c|c|c|c|c|}
\hline & $\begin{array}{c}\text { Hub } \\
\text { Height } \\
(\mathrm{m})\end{array}$ & Turbine Model & $\begin{array}{c}\text { Rotor } \\
\text { diameter } \\
(\mathrm{m})\end{array}$ & $\begin{array}{c}\text { Nominal Power } \\
(\mathrm{kW})\end{array}$ & $\begin{array}{c}\text { Start wind speed } \\
(\mathrm{m} / \mathrm{s})\end{array}$ \\
\hline WT-1 & 60 & BONUS & 76 & 2000 & 3 \\
\hline WT-2 & 80 & VESTAS & 90 & 2000 & 3 \\
\hline WT-3 & 78 & ENERCON E-82 & 82 & 2000 & 2 \\
\hline
\end{tabular}

Developed TRNSYS model was presented in figure 4. The system model consists of different subroutines called types (Al-Alili et al., 2012). After selecting each type, link connections are made. The PV array is composed of 10,000 PV modules. Solar irradiance, slope angle, azimuth angle, ambient temperature and incidence angle are the input parameters of the PV array. Monthly and yearly energy output of wind turbines and PV array were integrated with the use of periodic integrators (Type 55) and results were printed. 
TRNSYS 18 has different PV models. In this study, Type 103 was used for modelling. The model employs equations for an empirical equivalent circuit model to predict the currentvoltage characteristics of a single module and results for a single module are extrapolated to estimate the performance output of a multi-module array (Duffie and Beckman, 1991). Technical characteristics of the selected PV module was presented in Table 2. Dynamic simulations were carried out for 8760 hours (a year) with one hour time interval.

Table 2. The electrical characteristics of the PV arrays

\begin{tabular}{|l|l|l|l|}
\hline Parameter & Description & Value & Unit \\
\hline $\mathrm{P}_{\text {module }}$ & Unit peak power & 100 & $\mathrm{~W}$ \\
\hline $\mathrm{I}_{\mathrm{sc}, \text { ref }}$ & $\begin{array}{l}\text { Module short-circuit current at reference } \\
\text { conditions }\end{array}$ & 6.5 & $\mathrm{~A}$ \\
\hline $\mathrm{V}_{\mathrm{oc}, \mathrm{ref}}$ & $\begin{array}{l}\text { Module open-circuit voltage at reference } \\
\text { conditions }\end{array}$ & 21.6 & $\mathrm{~V}$ \\
\hline $\mathrm{V}_{\mathrm{mp}, \mathrm{ref}}$ & $\begin{array}{l}\text { Module voltage at max power point and } \\
\text { reference conditions }\end{array}$ & 17 & $\mathrm{~V}$ \\
\hline $\mathrm{I}_{\mathrm{mp}, \mathrm{ref}}$ & $\begin{array}{l}\text { Module current at max power point and } \\
\text { reference conditions }\end{array}$ & 5.9 & $\mathrm{~A}$ \\
\hline
\end{tabular}

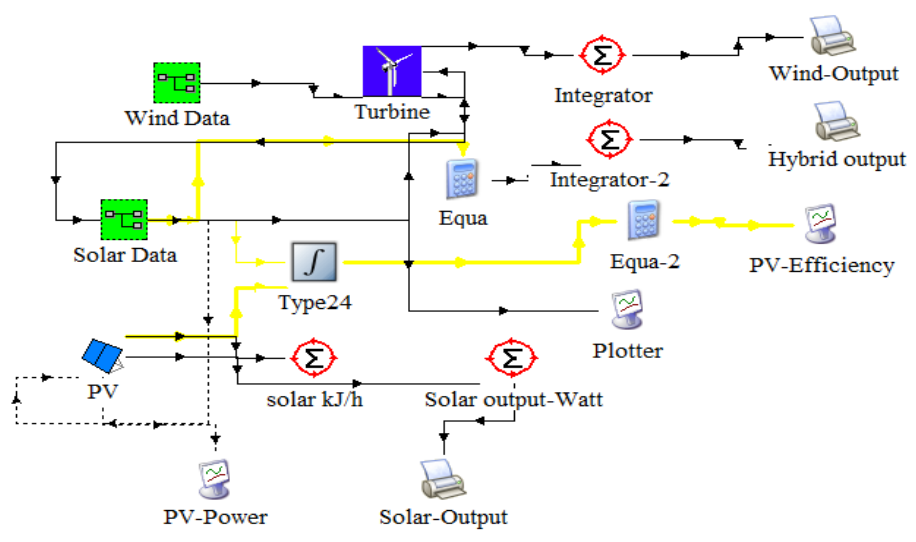

Figure 4:

System Model

\subsection{Solar Energy Potential of Bursa Province}

Solar energy has a high potential for generating electricity. For this reason, PV panels were applied to the hybrid system. Irradiation, ambient temperature, slope and azimuth angle have a significant effect on the power output of PV panels. Monthly global radiation of the year 2011 and 2014 were obtained from the Turkish State Meteorological Service and presented in figure 5. According to figure 5, total monthly global horizontal radiation was at the highest level in June with $319 \mathrm{kWh} / \mathrm{m}^{2}$ in 2011 , and with $308 \mathrm{kWh} / \mathrm{m}^{2}$ in 2014 , respectively. Total monthly global horizontal radiation was at the lowest level in December with $79 \mathrm{kWh} / \mathrm{m}^{2}$ in 2014 and with $56 \mathrm{kWh} / \mathrm{m}^{2}$ in 2011. 


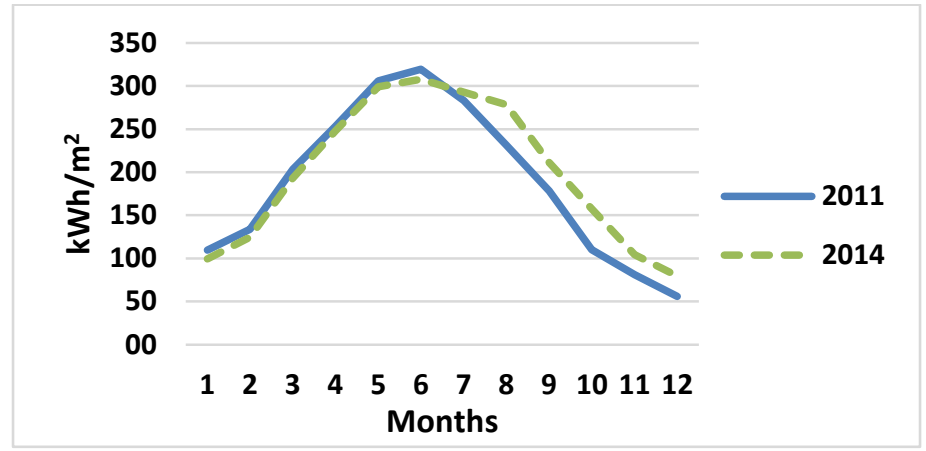

Figure 5:

Total monthly global horizontal radiation of Bursa for $0^{\circ}$ slope angle

PV modules are usually fixed at a certain slope angle. It is crucial to know the optimal slope angle of the PVs to use during the simulation (Panayiotou et al., 2012). In order to define the optimal slope angle to be used in the model, different slope angles were investigated, and results were presented in Figure 6 and 7. The results highlight that the amount of total annual solar energy available is at the peak for the slope of $35^{\circ}$. For the year 2011 , yearly total global solar radiation is $2263 \mathrm{kWh} / \mathrm{m}^{2}$ for $0^{\circ}$ slope angle and $2690 \mathrm{kWh} / \mathrm{m}^{2}$ for $35^{\circ}$ slope angle. Similarly, annual total global solar radiation is $2396 \mathrm{kWh} / \mathrm{m}^{2}$ for $0^{\circ}$ slope angle and 2883 $\mathrm{kWh} / \mathrm{m}^{2}$ for $35^{\circ}$ slope angle in 2014. Changing the slope angle from 0 to $35^{\circ}$ results an increase in the collected annual total global radiation by $19-20 \%$. As a result, simulations of PV panels were carried out by using this angle.

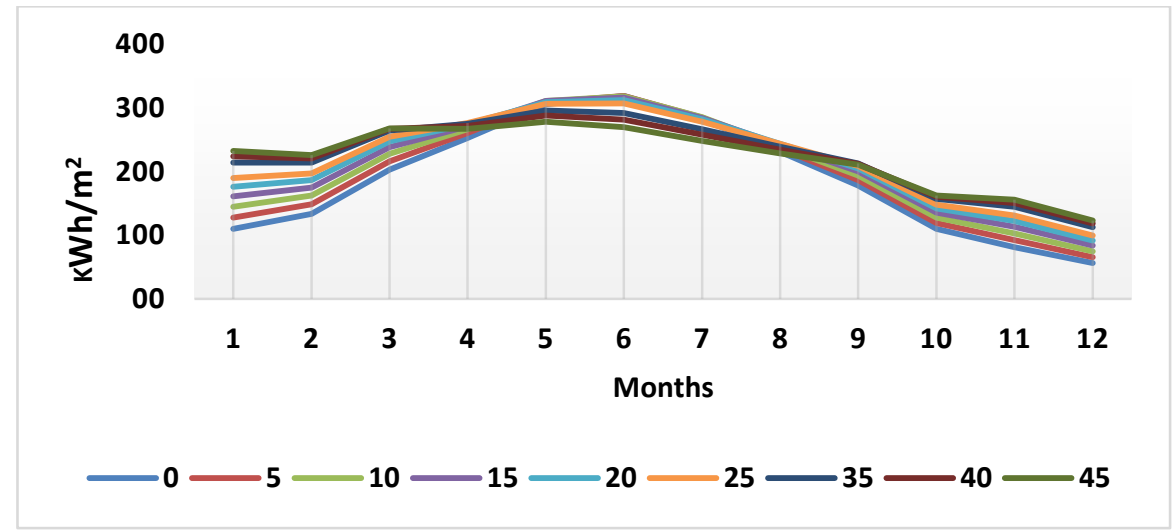

Figure 6:

Monthly Total Solar Radiation of Bursa Province for different slope angles $\left(0^{\circ}-45^{\circ}\right)$ in 2011

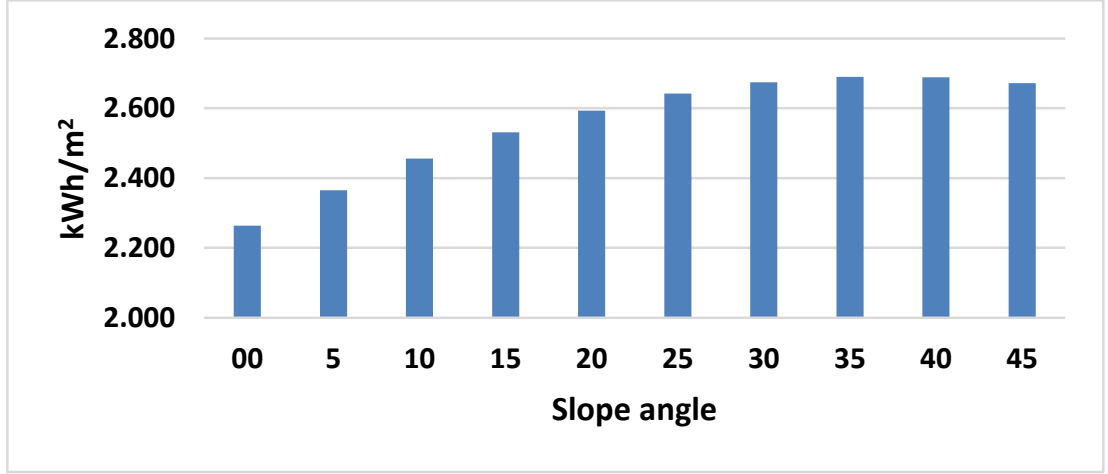

Figure 7:

Annual Total Solar Radiation of Bursa Province for different slope angles $\left(0^{\circ}-45^{\circ}\right)$ in 2011 


\subsection{Economic Analysis}

In order to evaluate the results of the study financially, an economic analysis was conducted. Cost of renewable energy systems is a major concern. As a result, levelized cost of energy (COE) and payback period (PBP) were considered for the hybrid system. Table 3 shows the parameters that were used in the calculations.

Table 3. Economic Parameters (Ramli et al., 2016)

\begin{tabular}{|l|l|l|l|}
\hline & PV Array & Wind turbine & Inverter \\
\hline Lifetime & 30 years & 20 years & 30 year \\
\hline Cost of Investment & $\$ 2000 / \mathrm{kW}$ & $\$ 3000 / \mathrm{kW}$ & $\$ 400 / \mathrm{kW}$ \\
\hline Cost of Replacement & $\$ 1200 / \mathrm{kW}$ & $\$ 1500 / \mathrm{kW}$ & $\$ 375 / \mathrm{kW}$ \\
\hline Cost of O\&M & $\$ 30 / \mathrm{kW} /$ year & $\$ 40 / \mathrm{kW} /$ year & $\$ 20 / \mathrm{kW} /$ year \\
\hline
\end{tabular}

$C_{N P C, t o t}$ is the net present cost of the system, whereas, $C_{a n n, t o t}$ is the annualized cost of the system. CRF is the capital recovery factor, $\mathrm{i}$ is the discount or interest rate, and it is assumed to be $\% 10$ and $\mathrm{N}$ is the lifetime of the system (Ramli et al. 2016). Levelized cost of energy (COE) can be defined as the ratio of the annualized cost of the system to the annual power output.

$$
\begin{gathered}
C_{N P C, t o t}=\frac{C_{\text {ann,tot }}}{C R F\left(i, R_{\text {proj }}\right)} \\
C R F(i, N)=\frac{i(1+i)^{N}}{(1+i)^{N-1}} \\
C O E=\frac{C_{\text {ann,tot }}}{E_{\text {served }}}
\end{gathered}
$$

Payback period (PBP) is the time needed for cumulative fuel savings to be equal to the total initial investment (Al-Alili et al. 2012). In order to investigate the economic feasibility of renewable energy system investments, PBP is an important indicator. In Eq. (7), $\mathrm{C}_{\mathrm{f}}$ is the unit price of the electricity obtained from the local utility supplier. It is $0.062 \$ / \mathrm{kWh}$ for the year 2019.

$$
P B P=\frac{\operatorname{In}\left(\frac{C_{N P C, \text { tot }} \times i}{E_{\text {served }} \times C_{f}}\right)}{\operatorname{In}(1+i)}
$$

\section{RESULTS AND DISCUSSION}

The dynamic simulations of a hybrid energy system consist of 2 MW wind turbines, and 1 MW PV panels were studied, and results were presented. Figure 8 and 9 show the power output of three different wind turbine models with 2 MW capacity for the weather data of 2011 and 2014 , respectively. It may be seen that the power output of the WT-2 is greater than the power output of other wind turbine models. The main reason behind that trend is the greater power generation of WT-2, specifically in low wind speed range. As a result, WT-2 was chosen for the hybrid energy system. Throughout the year of 2011, the greatest monthly total energy generation of WT-2 was achieved in April with 96 MWh energy generation, due to high wind speed. November has the lowest energy generation with $28.5 \mathrm{MWh}$ because of the lower wind speed. In the year of 2014, the greatest electricity utilization of WT-2 occurred in January with $127 \mathrm{MWh}$. 


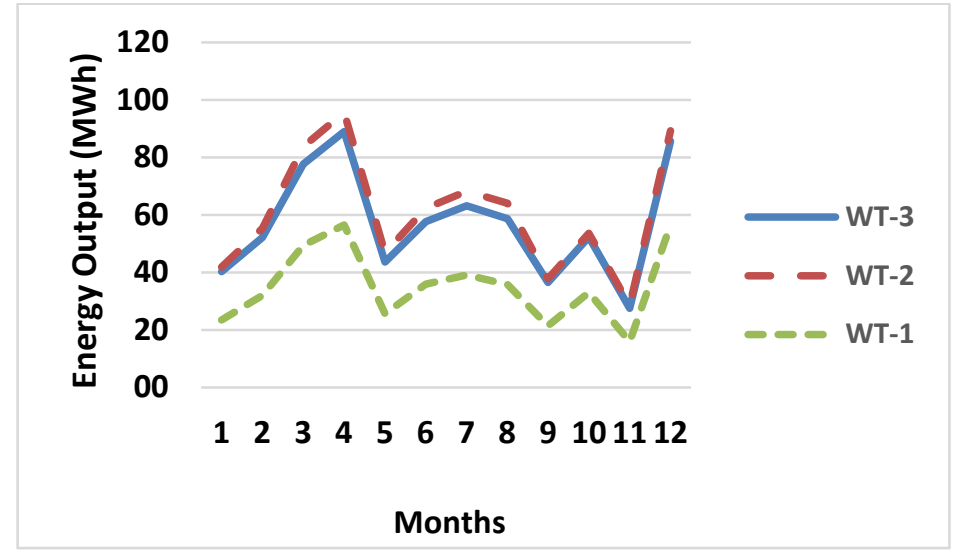

Figure 8:

Monthly total energy output of wind turbines at $10 \mathrm{~m}$ height (for the weather data of 2011)

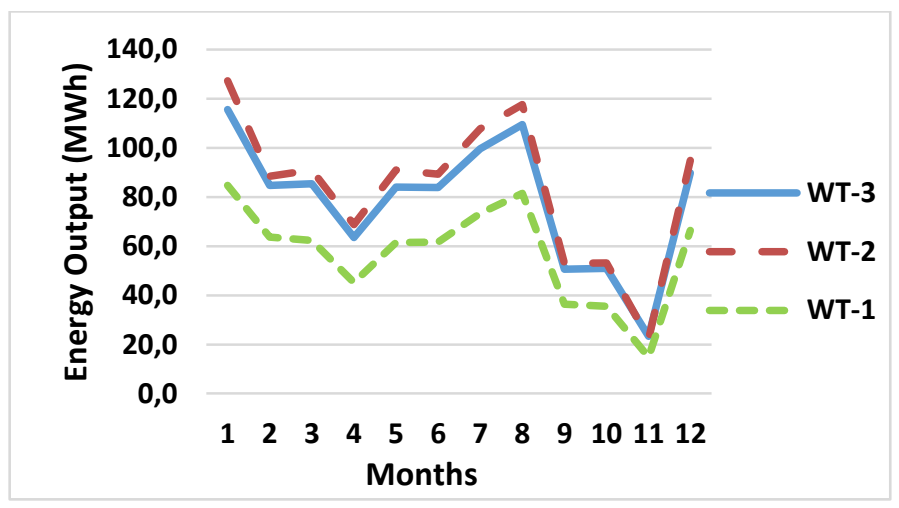

Figure 9:

Monthly total energy output of wind turbines at $10 \mathrm{~m}$ height (for the weather data of 2014)

Figure 10 shows monthly energy output expectations of WT-2 at heights of $10 \mathrm{~m}$ and $50 \mathrm{~m}$ above the ground. According to the results, the same turbine (WT-2) has better power output at higher heights. Compared to the annual energy output at $10 \mathrm{~m}$ height, annual energy output increases by $25 \%$ at the height of $50 \mathrm{~m}$. As a result, it was decided to install a wind turbine at 50 $\mathrm{m}$ height.

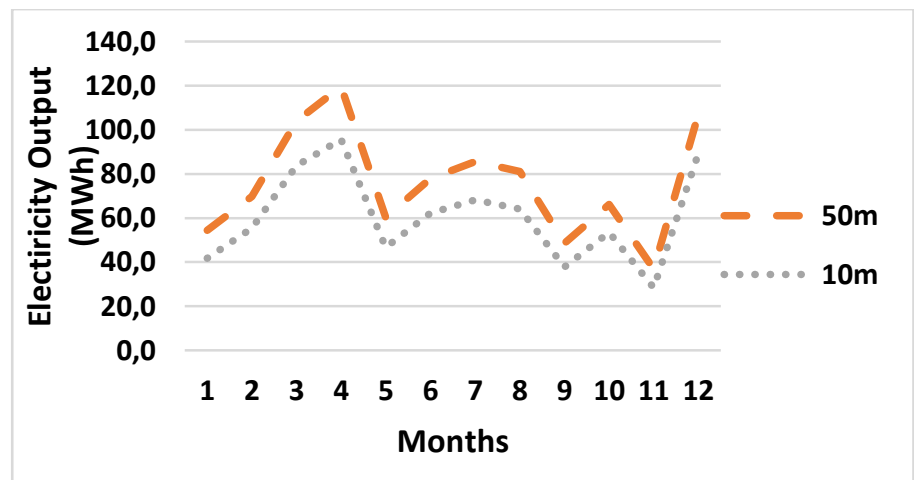

Figure 10:

Monthly total electricity output of WT-2 at $10 \mathrm{~m}$ and $50 \mathrm{~m}$ heights (for the weather data of 2011)

In figure 11, the total monthly power output of WT-2 was compared according to meteorological data of 2011 and 2014. Since wind speed is not stable, there are slight differences between the two years. The greatest energy output of WT-2 at $50 \mathrm{~m}$ height in 2011 was achieved in April with $120 \mathrm{MWh}$, and in 2014, it was achieved in January with $156 \mathrm{MWh}$. 
Lowest energy output occurred in November for the two years, 37 MWh for the 2011 and 30 MWh for 2014, respectively.

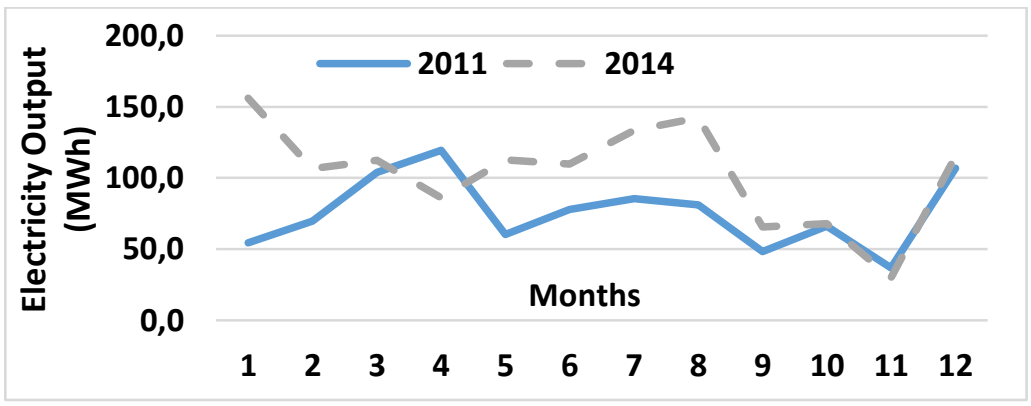

Figure 11:

Monthly total electricity output of WT-2 at 50m height, for the weather data of 2011 and 2014

Compared to the power output of WT-2 for the weather data of the two years, WT-2 has $36 \%$ greater power output for the data of 2014 because of the higher average wind velocities throughout that year. It can be concluded that for the weather conditions of Bursa, it is possible to generate 726 to $1000 \mathrm{MWh}$ electricity annually with a $2 \mathrm{MW}$ wind turbine at $10 \mathrm{~m}$ height above the ground. This can be increased to a value between 911 to $1240 \mathrm{MWh}$ at $50 \mathrm{~m}$ height above the ground.

Figure 12 shows the energy harvested from sunlight via $1 \mathrm{MW}$ PV panels for the weather data of 2014 and 2011. Results show that the monthly total obtained energy of the year 2014 and 2011 is very consistent, and there is only a slight difference. Results also show that the power harvested from PV panels is more stable and reliable than the power harvested from the wind turbine. As can be seen from the results, May has the highest amount of monthly energy output for the two years with 273 MWh in 2011 and 268 MWh in 2014, respectively. Similarly, December has the lowest total monthly power output with $111 \mathrm{MWh}$ in 2011 and with 155 MWh in 2014, respectively.

Despite the fact that solar radiation is abundant during summer months, it is insufficient during winter months. To maintain constant power generation, it is recommended to implement hybrid renewable energy systems. With the application of both solar-wind energy systems together, energy output and efficiency will be much greater.

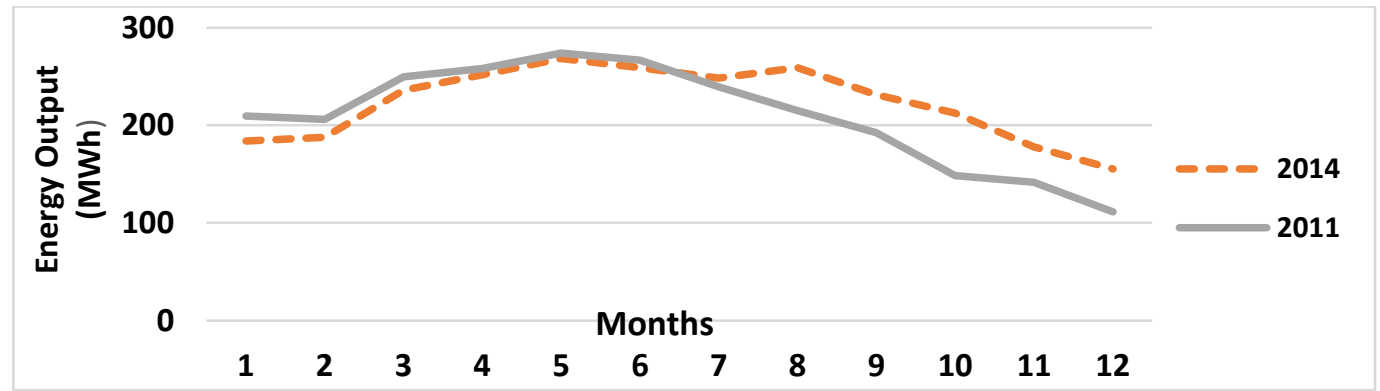

Figure 12:

Monthly total energy output of 1 MW PV system in Bursa (35 slope angle) in 2011, 2014.

The proposed hybrid system consists of $1 \mathrm{MW}$ capacity PV panels with $35^{\circ}$ slope, $0^{\circ}$ azimuth angle and $2 \mathrm{MW}$ capacity WT-2 wind turbine at $50 \mathrm{~m}$ height. Figure 13 and 14 show the energy output of the wind/solar hybrid system according to the weather data of the year 2011 and 2014, respectively. The total energy production of the hybrid system is 3423 MWh/year for the weather data of 2011 and $3909 \mathrm{MWh} /$ year for the weather data of 2014. 
Electric power consumption in Turkey was reported as $2855 \mathrm{kWh}$ per capita, for the year of 2014. With the assumption of each household has three occupants, annual energy generated by the hybrid system can provide enough electricity for 450 houses.

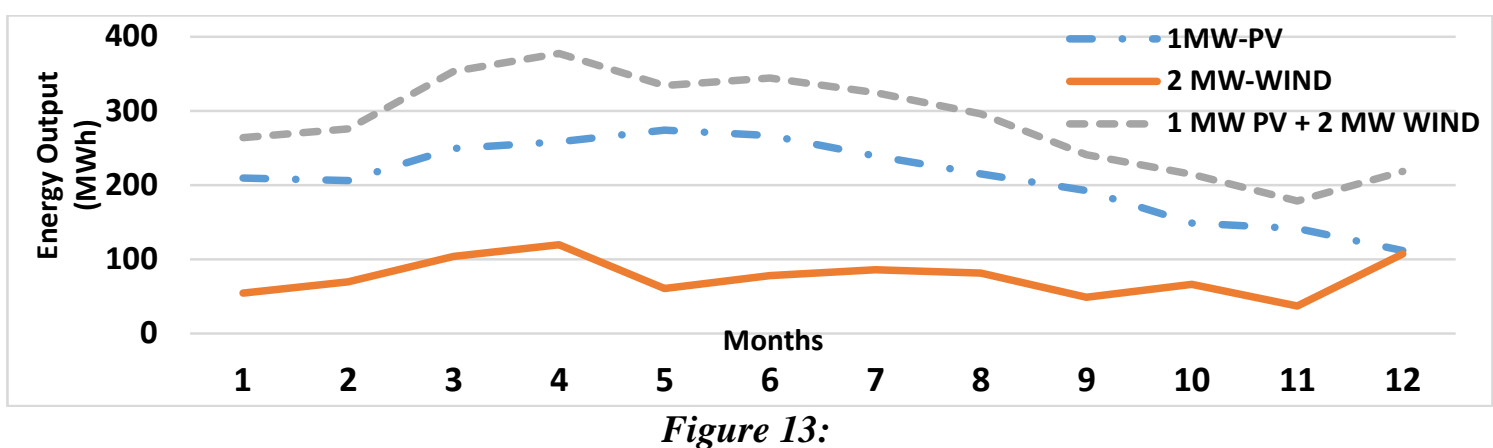

Monthly total energy output of the proposed hybrid system and single wind and single PV systems in 2011

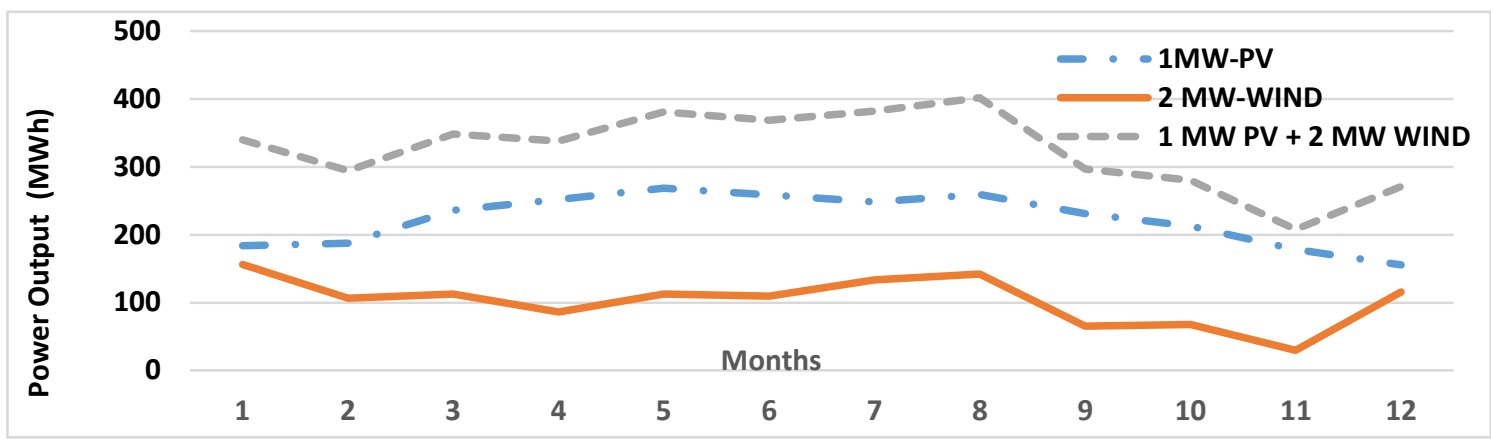

Figure 14:

Monthly total power output of the proposed hybrid system and single wind and single PV systems for the weather data of 2014.

Results of the economic analysis show that the levelized cost of energy (COE) is between 0.413-0.568 \$/kWh for the hybrid system. When compared the COE of the PV and wind system separately, the levelized cost of energy is more expensive for the wind turbines than that of the PV array because of the low mean wind velocity of Bursa throughout the year. This is mainly because of the less electricity generation by the wind turbine than that of the PV system. Payback period (PBP) of the hybrid system is between 19 to 20 years. This period can be considered quite long, and it approaches, even exceeds the useful lifetime of the wind turbines. As a result, governments should provide advantageous incentives to make renewable-based power systems economically feasible.

\section{CONCLUSIONS}

In this paper, dynamic simulation of a proposed wind/solar hybrid power system was carried out for the Bursa province with using real meteorological data of 2011 and 2014, and results were presented. The hybrid system operates without energy storage, and it is connected to the grid. The analysis is based on the specifications of the three different wind turbine models with the same capacity of 2 MW (WT-1, WT-2, and WT-3). Different parameters such as site elevation, the hub height of the wind turbine, ambient temperature, slope and azimuth angle of the PV panels are considered for achieving more accurate results. Results of the study are summarized below: 
- Wind speed has a significant influence on the turbine's power output. In general, monthly wind velocity of Bursa is between 2 to $4 \mathrm{~m} / \mathrm{s}$. Wind speed has a decreasing tendency from August to November and an increasing trend from May to August.

- Total monthly global horizontal radiation of Bursa is at the peak in June between 308 to $319 \mathrm{kWh} / \mathrm{m}^{2}$, and it is at the lowest level in December between 56 to $79 \mathrm{kWh} / \mathrm{m}^{2}$.

- For $35^{\circ}$ slope angle, annual total global radiation is at its maximum value. As a result, it was concluded that $35^{\circ}$ slope angle is the optimum value for PV panels.

- Power output expectations of the wind turbine increase at higher heights. Annual energy output increases by $25 \%$ at the height of $50 \mathrm{~m}$ when compared to $10 \mathrm{~m}$ above the ground.

- For the weather conditions of Bursa, it is possible to produce 726 to $1000 \mathrm{MWh}$ with a $2 \mathrm{MW}$ capacity wind turbine at $10 \mathrm{~m}$ above the ground, and this value can be increased to a value between 911 to 1240 , at $50 \mathrm{~m}$ height.

- With the application of wind turbines and solar panels together as a hybrid energy system, (1 MW capacity PV panels with $35^{\circ}$ slope angle and 2 MW capacity WT-2 type wind turbines at $50 \mathrm{~m}$ height) it is possible to generate electricity between 3423 to 3909 MWh per year. This amount is enough to compensate annual electricity load of 450 households which can be considered as a small village.

- The levelized cost of energy (COE) is found a value between $0.413-0.568 \$ / \mathrm{kWh}$ for the hybrid system; this is quite expensive than the conventional unit electricity price. Also, Payback period of the system is found a value between 19 to 20 years, which is a very long period. Therefore, it is important to offer adequate incentives for renewable-based power applications to make them economically beneficial.

\section{ACKNOWLEDGEMENTS}

Authors gratefully acknowledge the financial support provided by TUBITAK (Project no: 218M805).

\section{REFERENCES}

1. Acevedo, L., Uche, J., Del Almo, A. Cirez, F., Uson, S., Martinez, A., Guedea, I. (2016) Dynamic Simulation of a Trigeneration Scheme for Domestic Purposes Based on Hybrid Techniques, Energies, 9, 1013. doi:10.3390/en9121013.

2. Al-Alili A., Islam, M.D., Kubo, I., Hwang, Y., Radermacher, R. (2012) Modeling of a solar powered absorption cycle for Abu Dhabi, Applied Energy, 93, 160-167. doi: 10.1016/j.apenergy.2010.11.034.

3. Bakic, V. Pezo, M., Stevanovic, Z., Zivkovic, M., Grubor, B. (2012) Dynamical simulation of PV/Wind hybrid energy conversion system, Energy, 45, 324-328. https://doi.org/10.1016/j.energy.2011.11.063.

4. Bernal-Agustin, J.L. and Dufo-Lopez, R. (2009) Simulation and optimization of standalone hybrid renewable energy systems. Renewable and Sustainable Reviews, 13, 21112118. https://doi.org/10.1016/j.rser.2009.01.010.

5. Duffie, J.A. and Beckman W.A. (1991) Solar Engineering of Thermal Processes. Second Edition. New York: John Wiley \& Sons, Inc.

6. Elnaggar, M., Edwan, E., Ritter, M. (2017) Wind Energy Potential of Gaza Using Small Wind Turbines: A Feasibility Study, Energies, 10, 1229. doi:10.3390/en10081229. 
7. Erdil, A. and Erbiyık, H. (2015) Renewable Energy Sources of Turkey and Assessment of Sustainability, Procedia - Social and Behavioral Sciences, 207, 669 - 679. https://doi.org/10.1016/j.sbspro.2015.10.137.

8. Huang, Q., Shi, Y., Wang, Y., Lu, L., Cui, Y. (2015) Multi-turbine wind-solar hybrid system. Renewable Energy, 76, 401-407. https://doi.org/10.1016/j.renene.2014.11.060.

9. Kaya, M.N., Aksoy, M.H. and Kose, F. (2017). Renewable energy in Turkey: potential,current status and future aspects, International Journal of Engineering, ISSN: 1584-2665, 65-69.

10. Kok, B. and Benli, H. (2017). Energy diversity and nuclear energy for sustainable development in Turkey, Renewable Energy, 111, 870-877. https://doi.org/10.1016/j.renene.2017.05.001.

11. Panayiotou, G., Kalogirou, S. and Tassou, S. (2012) Design and simulation of a PV and a PV-Wind standalone energy system to power a household application, Renewable Energy, 37, 355-363. https://doi.org/10.1016/j.renene.2011.06.038.

12. Ramli, M.A.M., Hiendro, A., Al-Turki, Y.A. (2016) Techno-economic energy analysis of wind/solar hybrid system: Case study for western coastal area of Saudi Arabia. Renewable Energy, 91, 374-385. https://doi.org/10.1016/j.renene.2016.01.071.

13. Rohatgi J. and Vaughn N. (1994) Wind characteristics: an analysis for the generation of wind power. Alternative Energy Institute. West Texas A\&M University.

14. Tank, V. Bhutka, J., Harinarayana, T. (2016) Wind Energy Generation and Assessment of Resources in India, Journal of Power and Energy Engineering, 4, 25-38. doi:

10.4236/jpee.2016.410002. 